\title{
Factors Influencing Parents' Decisions on Choosing an Islamic Primary School in Bandung Indonesia
}

\section{| Dian Hidayati ${ }^{1}$ | Andi Arif Rifa' $i^{2, *}$ |}

\author{
${ }^{1}$ Education Management, \\ Ahmad Dahlan University, \\ Yogyakarta, Indonesia \\ ${ }^{2}$ Fakultas Tarbiyah, IAIN \\ Syaikh Abdurrahman Siddik \\ Bangka Belitung, Bangka, \\ Indonesia \\ *andiarifrifai@gmail.com
}

\begin{abstract}
The era of disruption has brought about the impact of fundamental changes in the digital-based information presentation globally. Easy access to information and communication through social networks makes children no longer care about the surrounding environment and tends to be "uncivilized". The condition makes parents try to instill a filter through the selection of schools with a religious character curriculum. That fact encourages the emergence of schools labeled with religion with "extra" religious curriculum offers. So, the considerations in choosing a school from a Muslim family, in particular, can indirectly be seen from the curriculum character offered by the school and the character of its graduates. The purpose of this study was to determine the factors that influence parents in choosing an Islamic school. The method used is quantitative with 100 parents who have school-age children from grade 1 to grade 3 who have a middle to the upper economic background in the Bandung. The results of the study found that the factors of parents choosing an Islamic primary school that has primary school graduates accustomed to speaking good words such as please, sorry, thank you and Toyyibah sentences, accustomed to pray 5 times a day, reading the Quran, memorizing the Quran and language skills (Indonesian and English) KEYWORDS

The era of disruption; choosing schools; curriculum character; Muslim families.
\end{abstract}

\section{INTRODUCTION}

The development of technology, particularly information technology brings a real impact on various aspects of life including children's education. On the other hand, the digitalization wave or known as the era of disruptors, has a profound impact on the field of information technology (G. Mulya, 2018). The era of disruption, the era of digital disruption, and digital steroids, primarily, cannot be separated from the Industrial Revolution 4.0, the era that is said to have started in Germany in 2011 and marked through the emergence of digital revolution (V. E. Satya, 2018). In the historical record perpetuated in various literature such as management and business, the industrial revolutions 1, 2 and 3 are contributed to the appearance of the industrial revolution 4.0 (D. L. Goetsch and S. Davis, 2013).

The information concerning the number of IT users and its enthusiast can be seen from the world internet users statistics. In 2016, there are 3.24 billion of 7.39 billion people in the world use the internet. The number is equal to $44 \%$ of the world's population and it will continue to increase. Furthermore, there are 2.31 billion social media users out of existing internet users, 3.8 billion of them use mobile phones, and 1.79 billion of them use their own mobile phones to support their activities. While in Indonesia, out of 259 million population, it is said that there are 88 million (33.98\%) internet users, 79 million (30.5\%) active users of social media and 66 million $(25.48 \%)$ users use their phones to access the internet (P. Rudito and M. F. N. Sinaga, 2017). 
Concerning this, Mohammad Fakry Gaffar said that the development of technology, especially IT, has a positive impact such as: automated economy, advanced knowledgebased economies, the emergence of artificial intelligence, online technology, communication revolution, and global interconnection (M. F. Gaffar, 2018). On the other hand, this condition also brings a negative impact especially for children, where it changes real world interaction to be digital communication. The fact shows that children tend to be anti-social if they are too preoccupied with social media (S. Fitri, 2017). More specifically, Times Indonesia noted that there are 8 negative impacts of social media for children including; cyber bullying, triggering crime, pornography, poor communication, threats of hate speech, negative emotional and physical development, and secret spreading (D. Mayasari, 2019). In addition, Merdeka.com added 4 negative impacts of social networking for children, namely; laziness, ignorance, difficulty to communicate, and the threat of predatory crime (F. Jamaludin, 2016). The negative impact of using information technology (such as gadgets) further can be minimized by the active role of the family (J. E. Palar, F. Onibala, and W. Oroh, 2018).

Nevertheless, the rapid growth cannot be blocked due to three supporting factors, namely; suitable product choices, the effectiveness of institutions which draws a lot of attention, and the use of technology along with the coordination of various policy instruments (A. Mody, 2005). Such conditions then help parents in realizing the importance of teaching morality and ethical values in order to cope with the effects of the era of disruption (Industrial Revolution 4.0). The exposure of school choice is needed by parents to conduct an evaluation in determining the suitable school which is corresponding with current conditions (the challenges of the times).

In the concept of Islamic Education, parents are responsible of their children's education. Family, in this matter, becomes the first and foremost educational institution, that is required to provide Islamic religious education and save their children from entering hell. These responsibilities, according to Umar bin Khattab, consist of three things, which are to choose a good mother for him, so that the child will not get hurt because of his mother. After that is to choose a good name for him, and lastly, to educate them with Qur'an (A. N. Ulwah, 2002). Apart from that, related to children's formal education, parents are responsible for their school choice. The option further will be vary from one parent to another.

Concerning this option, basically, parents are faced with two main choices: public school or private school. A study that is conducted in Malaysia by N. Alyani, M. Mohamed, and S. Bachok shows several reasons that lead parents into choosing private school for their children, namely the social background/status, the income level, the school syllabus, the school environment/facilities, the school performance, the location, the quality of the teachers, and also the distance. Among these factors, the income level, social background, the distance and also the location are the main factor why parents choose to enroll their children in private schools ( N. Alyani, M. Mohamed, and S. Bachok, 2015). Similar research was carried out by N. A. Yaacob, M. M. Osman, and S. Bachok Reasons. The results suggest that the school syllabus, the school environment and facilities, and the academic performance along with teacher quality become the main considerations before they ended up choosing private school (N. A. Yaacob, M. M. Osman, and S. Bachok, 2014).

Meanwhile, in Indonesia, several studies point out that parents are considering the following criteria before they decided which school will their children go to: First, several potential factors which make parents chose Islamic primary school or SD IT (Wuluhadeg and Assalam) are; the portion of Islamic education, the safety, the school achievement, the learning and teaching approach, and discipline factors (R. Verdiyani, 2016).

Second, several potential factors which make parents chose Virgo Maria 2 primary school and Islamic primary school or SDIP. H. Soebandi Kecamatan Bawen Kabupaten Semarang 
are; the location (dominant factor), customer satisfaction, and the culture of the school $(\mathrm{N}$. Khasanah, 2012). Third, several potential factors which make parents chose Kasatriyan Surakarta primary school for their children are; the school promotions, the services, and accreditation status. Meanwhile, the factors that are not taken into considerations are the product, cost, and location (N. Kristiani, 2016).

Fourth, the potential factors which make parents chose pesantren-based school (Islamic boarding school) like al-Muqaddasah are Qur'an education. This motive is influenced by the shift of social awareness towards education, from something capital to be more spiritual. The decision itself is the realization of material into meta-motivation shift of the parents (A. Bakar, 2014).

Fifth, the study conducted at Islamic-based school (MI Tahassus Prapagkidul Kecamatan Pituruh Kabupaten Purworejo) shows that the factors that motivate parents to enroll their children to this school include: The intrinsic factors sorted from the highest percentage to the lowest are noble morals, fiqh of worship knowledge, the Qur'an knowledge, religious knowledge, and achievement. The extrinsic factors sorted from the highest percentage to the lowest are school order, the portion of religious education, the teacher's profile, school vision and mission, extra-curricular activities, scholastic skills, the curriculum, the physical facilities, school location and environment, encouragement from family and community, and school tuition (R. N. L. Dewi, 2015)

Based on several studies that have been conducted, several factors that influence parents in choosing the right school for their children can be divided into three categories based on system analysis approach, as presented in the table below:

Table 1. Factors Influencing Parent's Decision in Choosing School

\begin{tabular}{|c|c|c|}
\hline School Input & School Process & School Output \\
\hline $\begin{array}{l}\text { - Social } \\
\text { - } \text { Background/status } \\
\text { - } \text { Location level } \\
\text { - } \\
\text { - Pistance } \\
\text { - } \text { Promotion } \\
\text { - } \text { Visitual values and Mission } \\
\text { - } \text { Family support } \\
\text { - } \text { Community support } \\
\text { - School tuition }\end{array}$ & $\begin{array}{l}\text { - School syllabus (curriculum) } \\
\text { - School environment/ facilities } \\
\text { (physical facilities) } \\
\text { - Teacher's quality (Teacher's } \\
\text { profile) } \\
\text { - School performance } \\
\text { - The portion of religious learning } \\
\text { - Safety } \\
\text { - Teaching and Learning approach } \\
\text { - } \text { Siscipline } \\
\text { - School culture } \\
\text { - School order } \\
\text { - } \text { Extra-curricular activities } \\
\end{array}$ & $\begin{array}{l}\text { - Academic } \\
\text { Performance } \\
\text { - Customer satisfaction } \\
\text { - Accreditation status } \\
\text { - The religious level of } \\
\text { the graduate (noble, } \\
\text { intelligent in terms of } \\
\text { fiqh and understanding } \\
\text { Qur'an, educated in } \\
\text { terms of religious } \\
\text { education) } \\
\text { - Scholastic skills }\end{array}$ \\
\hline
\end{tabular}

\section{METHOD}

This study employs quantitative approach with survey design (S. Azwar, 20014), (M. Singarimbun and S. Efendi, 1989). The design is chosen since it is in line with the purpose of the study which aimed to uncover the school choosing phenomenon experienced by parents along with its attributes. The data collecting process involved 100 respondents, consisted of parents of $1^{\text {st }}$ until $3^{\text {rd }}$ grade students, which have different educational background, currently in middle-high economic status, and live in different areas. The data were collected through questionnaire and then analyzed through descriptive analysis (Sugiyono, 2006). Descriptive analysis is done in order to illustrate the tendency of parents 
in the form of frequency distribution and percentage. After that, the conclusion is taken based on the highest tendency out of the answer.

\section{DISCUSSION}

The answers that are given by the respondents related to the school options are presented in Table 2.

Table 2. Parent's Decision of Primary School

\begin{tabular}{|l|r|r|}
\hline \multicolumn{1}{|c|}{ Answer Choices } & \multicolumn{2}{c|}{ Responses } \\
\hline Public Primary School & $2,22 \%$ & 2,22 \\
Private Primary School & $4,44 \%$ & 4,44 \\
Islamic-based Primary School & $86,67 \%$ & 86,67 \\
Pesantren-based Primary School & $0,00 \%$ & 0 \\
Not yet make a decision & $6,67 \%$ & 6,67 \\
\hline
\end{tabular}

Based on Table 2, parents tend to choose school that has Islamic-based label compared to others. It means the importance point of the chosen school is the effort to include and put religious values first in their activities.

Besides, the chosen school is also required to provide several services as presented below:

Table 3. Parental Preference for the School Characteristics

\begin{tabular}{|l|c|c|c|c|c|}
\hline \multicolumn{1}{|c|}{ School Characteristics } & $\begin{array}{c}\text { Very } \\
\text { Important }\end{array}$ & Important & $\begin{array}{c}\text { Less } \\
\text { Important }\end{array}$ & $\begin{array}{c}\text { Not } \\
\text { Important }\end{array}$ & $\begin{array}{c}\text { Weighted } \\
\text { Average }\end{array}$ \\
\hline Teaching Professionalism & $97.78 \%$ & $2.22 \%$ & $0.00 \%$ & $0.00 \%$ & 3.98 \\
\hline Religious Graduates & $93.33 \%$ & $6.67 \%$ & $0.00 \%$ & $0.00 \%$ & 3.93 \\
\hline Safe and Comfortable & $93.33 \%$ & $6.67 \%$ & $0.00 \%$ & $0.00 \%$ & 3.93 \\
\hline School Quality & $84.44 \%$ & $15.56 \%$ & $0.00 \%$ & $0.00 \%$ & 3.84 \\
\hline $\begin{array}{l}\text { Effective information } \\
\text { management system for } \\
\text { parents and school }\end{array}$ & $82.22 \%$ & $17.78 \%$ & $0.00 \%$ & $0.00 \%$ & 3.82 \\
\hline Outstanding Graduates & $80.00 \%$ & $20.00 \%$ & $0.00 \%$ & $0.00 \%$ & 3.8 \\
\hline $\begin{array}{l}\text { Complete facilities and } \\
\text { infrastructure }\end{array}$ & $80.00 \%$ & $20.00 \%$ & $0.00 \%$ & $0.00 \%$ & 3.8 \\
\hline School start time & $57.78 \%$ & $42.22 \%$ & $0.00 \%$ & $0.00 \%$ & 3.58 \\
\hline $\begin{array}{l}\text { The number of graduates } \\
\text { accepted in favorite junior } \\
\text { high school }\end{array}$ & $40.00 \%$ & $51.11 \%$ & $8.89 \%$ & $0.00 \%$ & 3.31 \\
\hline Close proximity & $31.11 \%$ & $55.56 \%$ & $13.33 \%$ & $0.00 \%$ & 3.18 \\
\hline Affordable tuition & $18.18 \%$ & $65.91 \%$ & $11.36 \%$ & $4.55 \%$ & 2.98 \\
\hline $\begin{array}{l}\text { Availability of shuttle } \\
\text { facilities }\end{array}$ & $17.78 \%$ & $51.11 \%$ & $31.11 \%$ & $0.00 \%$ & 2.87 \\
\hline $\begin{array}{l}\text { Prestigious School } \\
\text { (expensive tuition) }\end{array}$ & $2.22 \%$ & $17.78 \%$ & $55.56 \%$ & $24.44 \%$ & 1.98 \\
\hline
\end{tabular}

Based on the data presented in Table 3, there are at least 8 points that should be provided by the school according to parents, namely:

1) Professional educators.

2) Religious graduates.

3) A safe and comfortable environment.

4) Quality services.

5) An effective information management system 
6) Outstanding graduate.

7) A complete facilities and infrastructure.

8) An effective school start time.

Apart from the things that have already mentioned,the number of graduates accepted in favorite junior high school, close proximity, affordable school-tuition, and the availability of the shuttle service are turned out to be important for parents. On the other hand, the prestigious school with expensive school tuition is said to be unimportant factor for parents.

From several primary school criteria parents expected above, parents further anticipate the graduates from these schools to have the following characteristics:

1) Ethical and moral character; Accustomed to being in order, neat, polite, independent, empathetic, good-spoken, accustomed to the Toyyibah kalibat, accustomed to follow Islamic rules of dress, and responsible for the duties and actions.

2) Religiosity; Performing the five daily prayers in a timely manner, accustomed to charity, getting to know the obligatory worship and sunnah.

3) Commitment to the Qur'an; Have a love of the Qur'an, good Tahsin, have a memorization of at least 2 juz.

4) Academic Abilities; Bahasa Indonesia, English, Arabic and local languages, as well as math and science skills.

Generally, the results of this study are complement the results of previous studies on the factors that influence parents in choosing a private school, especially schools with Islamic character as the basis. Moreover, this research supports previous research conducted by $\mathrm{N}$. Alyani, M. Mohamed, and S. Bachok (N. Alyani, M. Mohamed, and S. Bachok, 2015), NA Yaacob, MM Osman, and S. Bachok (N. A. Yaacob, M. M. Osman, and S. Bachok, 2014), R. Verdiyani (R. Verdiyani, 2016), Abu Bakar (A. Bakar, 2014) and Rizka Nur Laela Dewi (R. N. L. Dewi, 2015).

\section{CONCLUSION}

The era of disruption is characterized by thetechnological developments epidemics in various aspects of life including education that lead parents to have a tendency towards the choices of religious school (Islamic-based school) for their children. The data shows that $86.67 \%$ of parents tend to choose Islamic-based school. Additionally, the schools must also be supported by professional educators, produce religious and outstanding graduates, provide not only good environment and quality, but also adequate information technology, along with complete facilities and effective learning time. Thus, with these conditions, it is expected that the graduates will be excellent in ethics and morality, religiosity, have commitment to the Qur'an, and also goodacademic skills.

\section{REFERENCES}

A. Bakar. (2014). "Preferensi Wali Santri Dalam Memilih Pendidikan Tingkat Dasar: Studi Kasus Di Pondok Tahfidz Al-Qur'an Al- Muqaddasah Nglumpang Mlarak Ponorogo,” J. Kodifikasia, vol. 8, no. 1, pp. 23-43.

A. Mody. (2005). Technology and Development in The Third Industrial Revolution. London: Taylor \& Francis e-Library.

A. N. Ulwah. (2002). Pendidikan Anak Dalam Islam, pentj. Jamaluddin Miri. Jakarta: Pustaka Amani.

D. L. Goetsch and S. Davis. (2013). Quality management for organizational excellence : introduction to total quality LK - https://uum.on.worldcat.org/oclc/755004259. Pearson Education. 
D. Mayasari. (2016). "8 Dampak Buruk Media Sosial Bagi Anak dan Remaja," www.timesindonesia.co.id, [Online]. Available: www.timesindonesia.co.id. [Accessed: 29-Sep-2019].

F. Jamaludin. (2016). "Waspada, ini 4 Efek Negatif Media Sosial Bagi Anak dan Remaja," www.merdeka.com. .

G. Mulya. (2018). “Aktualisasi Nilai-Nilai Pendidikan Jasmai Dalam Pembentukan Karakter Generasi Muda di Era Disrupsi Media.," Peran Pendidik. Jasm. Dalam Pembentukan Karakter Gener. Di Era Disrupsi Media, vol. 1, no. 1, pp. 1-10.

J. E. Palar, F. Onibala, and W. Oroh. (2018). "Hubungan Peran Keluarga dalam Menghindari Dampak Negatif Penggunaan Gadget Anak dengan Perilaku Anak dalam Penggunaan Gadget di Desa Kiawa 2 Kecamatan Kawangon Utara," Ejournal Keperawatan (e-Kp), vol. 6 , no. 2, pp. 1-8.

M. F. Gaffar. (2018)."The Impact of The 4IR Upon Leadership Practices in Hgiher Education," in 2nd International Conference on Research of Educational Administration and Management (ICREAM).

M. Singarimbun and S. (1989). Efendi, Metode Penelitian Survey. Jakarta: LP3ES.

N. A. Yaacob, M. M. Osman, and S. Bachok. (2014). "Factors Influencing Parents' Decision in Choosing Private Schools," Procedia - Soc. Behav. Sci., vol. 153, pp. 242-253.

N. Alyani, M. Mohamed, and S. Bachok. (2015). "An assessment of factors influencing parents' decision making when choosing a private school for their children : a case study of Selangor , Malaysia : for sustainable human capital," Procedia Environ. Sci., vol. 28, no. Sustain 2014, pp. 406-417.

N. Khasanah. (2012). "Faktor-Faktor Yang Mempengaruhi Orang Tua Dalam Pengambilan Keputusan Memilih Sekolah Dasar Swasta (SD Virgo Maria 2 dan SDIP. H. Soebandi Kecamatan Bawen Kabupaten Semarang)," Satya Widya, vol. 28, no. 2, pp. 137-146.

N. Kristiani. (2016). "Faktor-Faktor Yang Mempengaruhi Keputusan Orang Tua Siswa Memilih SD Kasatriyan Surakarta,” J. Manaj. Maranatha, vol. 16, no. 1, pp. 91-118.

P. Rudito and M. F. N. Sinaga. (2017). Digital Mastery, Membangun Kepemimpinan Digital Untuk Memenangkan Era Disrupsi. Jakarta: Gramedia Pustaka Utama.

R. N. L. Dewi. (2015). "Motivasi Orang Tua Memilih Sekolah Berbasis Agama Di MI Tahassus Prapagkidul Kecamatan Pituruh Kabupaten Purworejo," Universitas Negeri Yogyakarta.

R. Verdiyani. (2016). "Analisis Animo Masyarakat Dalam Memilih Sekolah Anak Di SD Wuluhadeg dan SD IT Assalaam," J. Pendidik. Guru Sekol. Dasar, vol. 5, no. 23, pp. 2262-2269.

S. Azwar. (2004). Metode Penelitian. Yogyakarta: Pustaka Pelajar.

S. Fitri. (2017). "Dampak Positif dan Negatif Sosial Media Terhadap Perubahan Sosial Anak,” Nat. J. Kaji. Penelit. Pendidik. dan Pembelajaran, vol. 1, no. 2, pp. 118-123.

Sugiyono (2006), Metode Penelitian Kuantitatif, Kualitatif dan R\&D. Bandung: Alfabeta. 